\title{
Vlastnosti úloh z obecné chemie vyplývající z analýzy přijímacího řízení na Př́rodovědeckou fakultu Univerzity Karlovy
}

\author{
The Qualities of Tasks in General Chemistry Based on the Analysis of Entrance \\ Procedure at the Faculty of Science, Charles University
}

\author{
Martin Šrámek ${ }^{1, *}$, (D) Milada Teplá1 \\ ${ }^{1}$ Př́rodovědecká fakulta, Univerzita Karlova, Albertov 6, Praha 2, Ceská republika; sramekm123@gmail.com
}

Článek představuje výsledky položkové analýzy oborových testů z chemie zadávaných pro účely přijímacího řízení na Přírodovědecké fakultě Univerzity Karlovy v letech 2016 až 2019. Cílem položkové analýzy, která byla zaměřena na úlohy z obecné chemie, bylo odhalit úlohy, které byly pro uchazeče o studium nejvíce obtížné a úlohy necitlivé tedy takové úlohy, které nedostatečně rozlišovaly úspěšné uchazeče od uchazečů neúspěšných. Obtížné úlohy byly identifikovány na základě vypočtení indexu obtížnosti. Necitlivé úlohy byly stanoveny na základě výpočtu koeficientů ULI(1/2) a RIR. Výsledky položkové analýzy odhalily, že pro uchazeče obtížným tématem je stavová rovnice ideálního plynu. Dále byla odhalena čtyři témata, která obsahovala alespoň jednu obtížnou úlohu (výpočet $\mathrm{pH}$, elektronová konfigurace, iontový součin vody a elektrolýza). Necitlivé úlohy byly detekovány u třech témat (tepelný rozklad látky, rychlostní rovnice a chemické rovnováhy). Necitlivost úlohy často souvisela s vysokým počtem kroků nutných $\mathrm{k}$ jejímu úspěšnému vyřešení.

Klíčová slova:
přijímací test, obecná
chemie, položková
analýza, obtížnost
položky, citlivost
položky.

Zasláno $10 / 2021$

Revidováno $10 / 2021$

Prijiato $12 / 2021$

This article introduces results of item analysis of chemistry tests used as a part of the admission procedure at the Faculty of Science, Charles University, between 2016 and 2019. The aim of the analysis focusing on general chemistry was to determine which tasks were the most troublesome for applicants and those with a low discrimination index. The troublesome tasks were found based on the calculation of difficult indexes whereas the item discrimination index was represented by ULI(1/2) and RIR coefficients. The results of the item analysis showed that ideal gas law is the hardest and only troublesome topic. Moreover, there were four topics including at least one troublesome item ( $\mathrm{pH}$ calculation, electron configuration, ion product calculation, and chemical equilibrium). Additionally, the analysis revealed three topics containing an item with a low discrimination index (thermal decomposition, rate law, chemical equilibrium) and, in many cases, its value decreased with a number of steps necessary for reaching the solution in the task.

Key words:
admission tests, general
chemistry, item analysis,
item difficulty, item
discrimination.

Received 10/2021

Revised $10 / 2021$

Accepted 12/2021

\section{1 Úvod}

Přijímací zkoušky na vysokou školu jsou milníkem pro studenty, kteří se na školu hlásí. Jsou však také důležitým podkladem pro vysoké školy, které studenty vzdělávají. Přijímací zkoušky totiž mohou napomoci odhalit úseky učiva, které pro žáky středních škol, budoucí studenty škol vysokých, mohou být obtížné. Vyučující se na tyto úseky studia mohou ve své výuce specificky zaměřit a tím pomoci studentům překonat překážky, které je ve studiu čekají. Pro př́rodovědné obory, mezi nimi i chemii, může být takový př́stup zásadní, protože se potýkají s vysokým procentem neúspěšných studentů, kteří studium nedokončí a přestupují na jiné obory, nebo studia ukončí (viz např. Pikálková et al., 2014).

Prezentovaný výzkum byl zaměřen na vzdělávací obor Chemie. Ten lze dále studovat na řadě vysokých škol, na kterých mohou úspěšní uchazeči o studium studovat odborné studijní programy (např. Biochemie, Chemie životního prostředí ad.) či programy zaměřené na přípravu budoucích učitelů předmětu chemie. Obě zmíněné skupiny studijních programů jsou nabízeny např. na Přírodovědecké fakultě Univerzity Karlovy (dále jen PřF UK), kde proběhl tento výzkum.

\section{Teoretická východiska}

\subsection{Oborový test jako jedna z forem přijímacího řízení}

Př́ijímací řízení by mělo mít co nejvyšší možnou predikční validitu, tedy schopnost předpovědět akademický úspěch daného studenta. Akademická úspěšnost udává, zda-li student dokončí zdárně první ročník studia, eventuálně dané studium jako celek (Brown, 2003). Výzkumem prediktorů akademické úspěšnosti se zabývá řada českých i zahraničních studií (např. Berger, 2012; Rubešová, 2009; Škaloudová, 2003). 
Uvedení autoři dochází shodně k závěru, že mezi validní prediktory akademického úspěchu, tj. úspěšného dokončení 1. ročníku, eventuálně studia, patří stř̌edoškolský prospěch. Rubešová (2009, str. 97) ve svém článku uvádí, že „kolísání konečného prưměru studentů můžeme vysvětlit ze 47 \% závislostí na předchozí úspěšnosti studia na středni škole. "Při současném zohlednění úspěšnosti v přijímacím řízení (oborový test $\mathrm{z}$ matematiky + oborový test $\mathrm{z}$ geografie) však dojde $\mathrm{k}$ nárůstu koeficientu determinace modelu na $62 \%$. Využití oborových testů v přijímacím řízení tedy přispívá k výběru vhodných uchazečů (Rubešová, 2009) a oborové testy patří taktéž mezi validní prediktory akademického úspěchu. Oba prediktory (středoškolský prospěch i výsledek v přijímacím testu na vysokou školu) se navzájem doplňují a společně lépe predikují úspěšnost studia sledovaného jedince (Šrámek et. al., 2020).

Přijímací řízení formou pouze jednoho oborového testu je od akademického roku 2017/2018 taktéž využíváno pro výběr vhodných uchazečů o studijní program Chemie na PřF UK. Oborový test si jednotliví uchazeči mohou zvolit v závislosti na profilu jednotlivých studijních oborů (matematika, chemie, nebo biologie). Informace o středoškolském prospěchu uchazeče se v aktuálních podmínkách přijímacího řízení na PřF UK již nevyžaduje (PřF UK, 2021).

Kromě predikce akademické úspěšnosti může využití oborových testů jako jedné z formy realizace přijímacího řízení sloužit ke zjištění úrovně výsledků vzdělávání v rámci předchozích stupňů studia.

\subsection{Analýza oborového testu z chemie se zaměřením na obecnou chemii - výsledky dosavadních studií}

Za účelem zvýšení kvality přijímacího řízení byly provedeny analýzy oborových testů na vysoké školy. V oblasti chemie provedly výzkum např. Belháčová (2002), Jedličková (2007), Martincová (2001) a Štefanová (2005). K dosažení uvedeného cíle využily všechny výše uvedené autorky položkovou analýzu, na jejímž základě interpretovaly zjištené poznatky. V rámci obecné chemie se došlo k následujícím závěrům:

Mezi úlohy s nízkým indexem obtížnosti (pro uchazeče obtížné úlohy) patři úlohy zaměřené na: (i) chemické rovnováhy (Martincová, 2001; Štefanová, 2005); (ii) termochemii (Martincová, 2005); (iii) teorii kyselin a zásad, včetně výpočtů pH (Belháčová, 2002; Jedličková, 2007; Stefanová, 2005) a (iv) poznatky plynoucí z trendů v periodické soustavě prvků (Jedličková, 2007; Štefanová, 2005).

Na druhou stranu mezi úlohy s vysokým indexem obtížnosti (pro uchazeče nejméně obtížné úlohy) patří (i) obecně úlohy z oblasti složení atomu (Martincová, 2001; (ii) výpočet reakčního tepla látky (Štefanová, 2005); (iii) tepelný rozklad látky (Štefanová, 2005) a (iv) vyčíslení chemické rovnice (Belháčová, 2002).

Martincová (2001) však poukazuje na závislost indexu obtížnosti s konkrétním zadání úlohy a vytýčila témata, do kterých spadaly úlohy $\mathbf{s}$ různorodou náročností závisející právě na konkrétním zadání. Jednalo se o úlohy zaměřené na (i) práci s oxidačními čísly; (ii) teorii kyselin a zásad, včetně výpočtů pH a (iii) poznatky plynoucí z trendů v periodické soustavě prvků (Martincová, 2001). Na souvislost indexu obtížnosti s konkrétním zadáním a taktéž počtem kroků nutných k vyřešení úlohy poukazuje též Cowan (2001), Miller (1985) či Čipera et al. (1956).

Problematika úloh a obsahu přijímacího testu $\mathrm{z}$ chemie byla řešena i $\mathrm{v}$ zahraničí - např. $\mathrm{v}$ rámci studie Herridge (2016). Autorka studie identifikovala ve své práci ty oblasti obecné chemie, které vnímají studenti (shodně s míněním vyučujících) v základním kurzu chemie na vysoké škole jako obtížné. V souladu se zjištěními ve shora uvedených studiích uvádí autorka, že jako nejvíce obtížné vnímají studenti i učitelé odvozování vlastností prvků a sloučenin na základě obecných znalostí periodické soustavy prvků (konkrétně je uvedena elektronová konfigurace, elektronová afinita, velikost atomů, reaktivita a ionizační energie). Další výzkum autorky v průběhu semestru odhalil s tím související problémy, jakými je vnímaná náročnost při určování produktů reakcí. Na konci semestru uváděli studenti jako komplikovaná témata chemickou rovnováhu, práci s oxidačními čísly a některé typy výpočtů např́iklad molární koncentraci. Výpočet $\mathrm{pH}$ vnímali studenti jako průměrně náročný. S podobnými výsledky přichází studie Tilahun a Tirfu (2016), která v souladu se shora uvedenými autorkami uvádí mj. jako obtížné téma chemickou rovnováhu a téma termochemie.

\section{Cíle a výzkumné otázky}

Hlavním cílem prezentované studie bylo zmapovat nejvíce obtížné úseky z učiva středoškolské chemie se zaměřením na obecnou chemii, které vyplývají z analýzy oborového testu chemie zadávaného na PřF UK v letech 2016 až 2019 a navázat tak na výsledky dřive realizovaných studií. Druhým neméně důležitým cílem bylo zjistit, které úlohy z oblasti obecné chemie nejméně přispívaly k výběru úspěšných uchazečů na PřF UK (tedy byly nejméně citlivé). Výsledky analýzy budou reflektovány při tvorbě oborových testů z chemie použitých v rámci přijímacího řízení. 
Vzhledem k výše vymezeným cílům studie byly stanoveny následující výzkumné otázky:

1. Které úlohy z obecné chemie zařazené do oborového testu byly obtížné pro uchazeče o studium na PřF UK?

2. Které úlohy z obecné chemie zařazené do oborového testu nedostatečně rozlišovaly úspěšné a neúspěšné uchazeče o studium na PřF UK?

3. Které úlohy z obecné chemie zařazené do oborového testu vykazovaly dostatečnou citlivost a zároveň adekvátní obtížnost?

\section{Metodologie}

Výzkumný vzorek byl tvořen 1780 uchazeči o studijní obor Chemie. Výzkumnými nástroji bylo 8 oborových testů z chemie zadaných v řádných termínech přijímacího řízení v letech 2016 až 2019 (viz tab. 1). Každý test obsahoval 30 uzavřených úloh s výběrem jedné správné odpovědi ze čtyř nabízených alternativ. Přibližně 25 až $30 \%$ z celkového počtu úloh bylo zaměřených na obecnou chemii, zbývající úlohy se zaměřovaly na anorganickou chemii, organickou chemii a biochemii. Aby bylo možné zodpovědět výše stanovené výzkumné otázky, byla u každého testu provedena položková analýza úloh z obecné chemie. Dále byly určeny následující parametry - úspěšnost, koeficient ULI(1/2), koeficient RIR (Chvál et al., 1999; Chráska, 2015; Varma, 2020).

Tab. 1: Počty uchazečů absolvující danou variantu testu

\begin{tabular}{lrrrrrrrrr}
\hline Test & $2016-$ & $2016-$ & $2017-$ & $2017-$ & $2018-$ & $2018-$ & $2019-$ & $2019-$ & Celkem \\
& $\mathrm{A}$ & $\mathrm{B}$ & $\mathrm{A}$ & \multicolumn{1}{c}{$\mathrm{B}$} & $\mathrm{A}$ & \multicolumn{1}{c}{$\mathrm{B}$} & $\mathrm{A}$ & $\mathrm{B}$ & \\
\hline Počet uchazečů & 219 & 220 & 230 & 221 & 238 & 213 & 223 & 216 & 1780 \\
Počet úloh z obecné chemie & 9 & 9 & 10 & 10 & 8 & 8 & 9 & 9 & 72
\end{tabular}

Vzhledem k tomu, že podkladem pro tvorbu oborových testů zadávaných na PřF UK slouží běžně dostupné středoškolské učebnice chemie a též Rámcové vzdělávací programy pro gymnázia (PřF UK, 2021), bylo pro stanovení obsahové validity zkoumáno zařazení konkrétních témat obecné chemie v Rámcovém vzdělávacím programu pro gymnázia (RVP G) (MŠMT, 2007) a též ve středoškolských učebnicích chemie. Z toho důvodu byla provedena obsahová komparace úloh s obsahem středoškolských učebnic chemie, které Huvarová (2010) ve svém výzkumu označila za nejčastěji používané. Konkrétně se jednalo o učebnice autorů: Mareček a Honza (2002), Mareček a Honza (2005a), Vacík (2005b) a Benešová (1999). Obsahová komparace byla provedena též z důvodu, že lze předpokládat, že žáci středních škol právě ze středoškolských učebnic čerpají své poznatky při přípravě na přjijímací řízení.

Konstruktová validita úloh je u přijímacího testu na PřF UK stanovována expertním panelem, který se skládá ze tří tvůrců testů, a dále jedním až dvěma kontrolory. Experti mj. posuzují proveditelnost, čtivost, konzistenci stylu, či jasnost vyjadřování (srov. Taherdoost, 2016).

\subsection{Stanovení obtížných úloh}

Aby mohla být nalezena odpověd’ na první výzkumnou otázku, byla pomocí položkové analýzy úloh stanovena jejich obtížnost. Ta byla vymezena prostřednictvím úspěšnosti uchazečů v dané úloze, která je definována jako podíl uchazečů, kteří úspěšně vyřešili danou úlohu, a celkového počtu uchazečů (Chvál et al., 2015). Za obtížnou úlohu byla následně považována taková položka, v níž byla úspěšnost uchazečů méně než $30 \%$. Hranice úspěšnosti $30 \%$ byla zvolena s ohledem na skutečnost, že všechny úlohy byly uzavřenými úlohami, kdy uchazeč volil správnou odpověd’ z právě čtyř alternativ. Tato forma úlohy má za následek, že pouhým hádáním lze dosáhnout statistické úspěšnosti rovné $25 \%$.

Aby bylo možné vymezit, která témata z obecné chemie jsou pro uchazeče nejvíce náročná, byla každá úloha, která byla shledána jako obtížná, následně zařazena do tematického celku z oblasti obecné chemie. $\mathrm{V}$ případě, že úspěšnost úloh spadajících do daného tematického celku nepřesahuje $30 \%$, je tento okruh úloh označen jako obtížné téma. V případě, že úspěšnost alespoň jedné úlohy v daném tematickém celku dosahuje nižší hodnoty než $30 \%$ a zároveň daný tematický celek obsahuje úlohy s průměrnou úspěšností převyšující $30 \%$, je tento okruh úloh označen jako potenciálně-obtížné téma. Zbývající témata lze nahlížet jako témata s adekvátní či nižší obtížností (resp. adekvátní či vyšší úspěšností), jelikož úspěšnost ve všech úlohách převyšovala $30 \%$ dle Šrámka et. al. (2021). 


\subsection{Stanovení úloh nedostatečně rozlišujících úspěšné uchazeče od uchazečů neúspěšných}

Aby mohla být nalezena odpověd’ na druhou výzkumnou otázku, byla u každé úlohy vypočtena její citlivost, která indikuje, zda úloha dostatečně rozlišuje úspěšné a neúspěšné uchazeče. K tomu byly použity koeficienty ULI $(1 / 2)$ a RIR. Koeficient ULI(1/2) byl vypočten následujícím způsobem. Uchazeči, kteří řešili danou úlohu byli rozděleni na dvě stejně velké skupiny dle celkového skóre dosaženého v daném testu. Pro každou skupinu byl vypočten index obtížnosti dané úlohy. Rozdíl těchto hodnot je následně roven právě koeficientu ULI(1/2) (Chvál et al., 2015). Koeficient RIR byl u každé úlohy určen tak, že byl vypočítán korelační koeficient mezi bodovým ziskem každého uchazeče v dané položce a jeho celkovým počtem v testu bez započtení bodů za danou položku (Chvál et al., 2015).

Pro účely prezentované studie byla úloha považována za citlivou, jestliže v případě výpočtu koeficientu ULI(1/2) došlo k naplnění jedné z následujících podmínek: (i) obtížnost úlohy je mezi 0,2 až 0,3 a zároveň hodnota vypočteného koeficientu ULI(1/2) je vyšší nebo rovna 0,15 ; (ii) obtížnost úlohy je mezi 0,3 až 0,7 a zároveň hodnota vypočteného koeficientu ULI(1/2) je vyšší nebo rovna 0,25 a (iii) obtížnost úlohy je mezi 0,7 až 0,8 a zároveň hodnota vypočteného koeficientu ULI(1/2) je vyšší nebo rovna 0,15 (Chráska, 1999). Při využití koeficientu RIR je za citlivou úlohu považována taková, jejíž hodnota tohoto koeficientu byla alespoň 0,15 s tím, že velmi dobré úlohy vykazují koeficient RIR vyšší než 0,25 (Varma, 2020). Citlivost byla ve spojitosti s jejich úspěšností odstupňovaná, nebot u úloh s úspěšností do $30 \%$ (či naopak u úloh s úspěšností velmi vysokou) bývá v literatuře snížen požadavek na koeficienty citlivosti (ULI(1/2) a RIR) s ohledem na jejich zvýšenou náročnost (Chráska, 1999; Varma, 2020).

Úloha byla považována za necitlivou, jestliže hodnota obou koeficientů citlivosti $(\mathrm{ULI}(1 / 2)$ a zároveň RIR) byla nedostatečná dle výše uvedených kritérií. Každá úloha, která byla shledána jako necitlivá, byla následně zařazena do tematického celku z oblasti obecné chemie, aby mohly být predikovány důvody její necitlivosti. $\mathrm{V}$ tomto případě byly rovněž posuzovány všechny položky, které svým zaměřením spadaly do vymezeného tematického celku v př́padě, že daná úloha nebyla v daném tématu jediná.

\subsection{Stanovení dostatečně citlivých úloh s adekvátní obtížností}

Aby mohla být nalezena odpověd’ na třetí výzkumnou otázku, byla opět pomocí položkové analýzy úloh stanovena jejich obtížnost a citlivost. Za dostatečně citlivé úlohy s adekvátní obtížností byly označeny úlohy s úspěšností mezi $30 \%$ a $80 \%$ (tedy úlohy ne příliš obtížné, a ne př́liš snadné) a zároveň se jedná o úlohy, které na základě definice uvedené v kapitole 3 lze označit jako citlivé.

\section{Výsledky a diskuze}

\subsection{Analýza obtížných úloh}

Analýza úloh z obecné chemie odhalila jedno obtížné téma a čtyři potenciálně-obtížná témata vyžadované v rámci přijímacího řízení. Mezi obtížná témata obecné chemie, tedy taková, ve kterých úspěšnost jednotlivých položek nepřesáhla $30 \%$, patřila stavová rovnice ideálního plynu včetně výpočtu na základě zápisu chemické rovnice. Toto téma bylo hlavním předmětem tří úloh. Dvě úlohy byly zaměřeny na výpočet změny tlaku, která nastala v důsledku hoření práškové glukosy v uzavřené nádobě. Obě úlohy vykazovaly úspěšnost přibližně $20 \%$. Navzdory skutečnosti, že obě úlohy měly téměř shodné zadání (pouze různé pořadí nabízených alternativ), dosahovala citlivost různých hodnot - ULI(1/2) hodnoty 0,16 , resp. 0,25 ; RIR hodnoty 0,18 , resp. RIR 0,29 . S ohledem na náročnost úlohy se tedy jedná o položky s přijatelnou citlivostí. Pro vyřešení úlohy bylo zapotřebí provést větší počet kroků nutných k jejímu vyřešení (zápis a následné vyčíslení chemické rovnice, výpočet změny látkového množství plynných složek, dosazení do stavové rovnice pro ideální plyn a porovnání změny tlaku v souvislosti se změnou teploty a též změnou látkového množství). Třetí úlohou byla úloha, která byla zaměřena na reakci železa s kyselinou sírovou za laboratorních podmínek. Úspěšnost této úlohy činila $25 \%$ a lze předpokládat, že nízká úspěšnost úlohy souvisela se zvolením laboratorních podmínek nikoliv podmínek normálních. Navzdory poměrně nízké úspěšnosti vykázala tato položka velmi vysokou citlivost - $\mathrm{ULI}(1 / 2)=0,30, \mathrm{RIR}=0,36$. Na základě analýzy výše uvedených učebnic bylo zjištěno, že úlohy obdobného typu nebyly v těchto učebnicích středoškolské chemie uvedeny. V Přehledu středoškolské chemie autorů Vacíka a kol. (1999) byla sice uvedena stavová rovnice, avšak ani jeden z řešených př́ikladů neobsahoval aplikaci daného vztahu.

$\mathrm{Na}$ druhou stranu mezi analyzovanými položkami bylo dalších osm úloh, ve kterých byl při výpočtu použit výpočet objemu plynu za normálních podmínek (teplota $0{ }^{\circ} \mathrm{C}$, tlak $101,325 \mathrm{kPa}$ ) $\mathrm{s}$ tím, že tyto položky vykazovaly vyšší úspěšnost (62\% až $90 \%)$ i citlivost - koeficienty ULI(1/2) a RIR nabývaly hodnot na intervalu 0,15 až 0,46 , tedy jednalo se o úlohy s akceptovatelnou až velmi dobrou citlivostí. 
$\mathrm{V}$ rámci analyzovaných úloh lze shrnout, že pokud k vyřešení úlohy je nutné použít výpočet objemu plynu za normálních podmínek, jedná se o úlohy vhodné pro přijímací řízení. V RVP G není explicitně učivo stavová rovnice ideálního plynu ani učivo molární objem plynu zmíněno, avšak témata lze zařadit $\mathrm{k}$ učivu výpočty v chemii.

Mezi potenciálně-obtižná témata chemie patřila tato témata: (i) výpočet $\mathrm{pH}$; (ii) elektronová konfigurace (určování počtu volných nevazebných elektronových párů částic); (iii) iontový součin vody a (iv) elektrolýza.

Úlohy zaměřené na výpočet $p H$ se velmi lišily svou obtížností. Okruhem úloh s nízkou úspěšností byl výpočet $\mathrm{pH}$ směsi, která vznikla smícháním roztoku hydroxidu a roztoku kyseliny. Tento typ úlohy byl zadán celkem v šesti úlohách - u všech těchto úloh se pohybovala úspěšnost mezi $18 \%$ a $27 \%$, koeficienty citlivosti se pohybovaly mezi hodnotami 0,13 a 0,42 . S ohledem na velmi vysokou náročnost úlohy se tedy obecně jednalo o položky s akceptovatelnou až velmi dobrou citlivostí. Zvýšená náročnost tohoto typu úloh byla zaznamenána již v přechozích studiích - např. Belháčové (20092002) a v některých úlohách též u Martincové (20012001). Nelze však tvrdit, že téma výpočty pH je jako celek téma náročné, nebot úlohy zaměřující se na výpočet pH roztoku kyseliny vykazovaly poměrně vysokou úspěšnost $(76 \%)$ i přijatelnou citlivost $-\mathrm{ULI}(1 / 2)=0,18 ; \mathrm{RIR}=0,20$, což je v souladu se závěry Ruska et. al 2021. Úlohy spadající do tohoto tématu ve vztahu k RVP G lze téma zařadit opět k učivu výpočty v chemii.

Druhým potenciálně-obtížným tématem bylo určování počtu volných nevazebných elektronových párů částic. Do tohoto tématu bylo zařazeno celkem 5 položek, jejichž průměrná úspěšnost se velmi lišila a pohybovala od $23 \%$ do $79 \%$ s přijatelnou citlivostí jednotlivých položek s ohledem na úspěšnost každé z nich. Úlohy v tomto tématu bylo možné rozdělit do tři kategorií:

a) určení počtu volných elektronových párů částice;

b) porovnání počtu volných elektronových párů částice;

c) zařazení prvku do skupiny na základě elektronové konfigurace.

Úspěšnost úloh, které spadaly do první zmíněné kategorie (např. Určení počtu volných elektronových párů sulfidového aniontu), dosahovala nízkých hodnot (přibližně $27 \%$ ), koeficienty citlivosti se pohybovaly mezi 0,14 a 0,33, což lze s ohledem na náročnost úloh považovat za přijatelnou až velmi vysokou citlivost. Do druhé zmíněné kategorie spadala pouze jedna úloha, ve které bylo zadáno 5 částic (atomů či iontů) a úkolem uchazečủ bylo vybrat částice se shodným počtem volných elektronových párů. Tato úloha vykazovala velmi dobré parametry - úspěšnost $44 \%$, koeficienty citlivosti - ULI $(1 / 2)=0,32 ; \mathrm{RIR}=0,37$, což svědčí o velmi vysoké citlivosti. Uvedené výsledky korespondují se závěry Martincové (2001), která upozorňuje na nedostatečné porozumění některých pojmů - např. volný elektronový pár. Ve třetí uvedené kategorii byly dvě úlohy, jejichž úspěšnost činila 78 \%, resp. $79 \%$ a koeficienty citlivosti se pohybovaly mezi 0,13 a 0,31 , což lze s ohledem na poměrně nízkou náročnost úloh považovat za přijatelnou citlivost. $\mathrm{Z}$ uvedených dat plyne, že způsob zadání úlohy z tohoto tématu chemie silně ovlivňuje úspěšnost, nikoliv však citlivost položky. V RVP G učivo nevazebné elektronové páry není explicitně zmíněno, nicméně téma lze zařadit $\mathrm{k}$ učivu stavba atomu a chemická vazba.

Třetím potenciálně-obtížným tématem byl iontový součin vody. Toto téma obsahovalo čtyři úlohy. Dvě úlohy byly zaměřeny na výpočet iontového součinu vody, dalš̌ dvě na souvislost mezi iontovým součinem vody a koncentrací oxoniových, resp. hydroxidových iontů. Obtížnější z úloh zaměřených na výpočet iontového součinu vody (výpočet iontového součinu vody na základě zadané koncentrace hydroxidových aniontů při dané teplotě) dosahovala hodnoty úspěšnosti $25 \%$, dále pro tuto úlohu byly vypočteny koeficienty $\operatorname{ULI}(1 / 2)=0,18$ a $\operatorname{RIR}=0,14$, které poukazují na citlivost úlohy blížíí se hranici přijatelnosti a svědčící spíše o tom, že jak úspěšní tak neúspěšní řešitelé správnou odpověd’ pouze tipovali. Druhá úloha spadající do téže kategorie dosahovala úspěšnosti $38 \%$ a velmi výborné citlivosti $\operatorname{ULI}(1 / 2)=0,34$, $\mathrm{RIR}=0,43$. Do druhé kategorie spadaly úlohy (vztah mezi koncentrací hydroxidových a oxoniových iontů) s relativně vyšší úspěšností (úspěšnost dosahovala $54 \%$, resp. $56 \%$ ) a s koeficienty citlivosti mezi 0,23 až 0,34 , což svědčí o vysoké citlivosti daných úloh. Co se týče analýzy tématu v učebnicích chemie, bylo téma iontový součin vody zmíněno spíše okrajově, např. v učebnici autorů Vacík et al. (1999). V RVP $\mathrm{G}$ učivo iontový součin není přímo zmíněno, avšak lze jej zařadit k učivu výpočty v chemii a chemická rovnováha.

Posledním potenciálně-obtížným tématem bylo téma elektrolýza, které bylo obsaženo ve dvou typech úloh. Prvním typem je elektrolýza směsi látek (s využitím zadaných elektrodových potenciálů), druhým typem je elektrolýza chemicky čisté látky. Dvě úlohy zaměřující se na elektrolýzu směsi látek vykazovaly úspěšnost $21 \%$, resp. $39 \%$. Koeficienty citlivosti těchto úloh se pohybovaly na intervalu 0,02 až 0,25 , což svědčí o nedostatečné, popř. omezené citlivosti daných položek. Výrazně odlišnou úspěšnost (přesahující $70 \%$ ) vykazovaly dvě úlohy zaměřující se na elektrolýzu čisté látky. Tyto položky vykazovaly též velmi vysokou citlivost - koeficienty citlivosti ležely na intervalu 0,30 až 0,42 . Z uvedených dat je možné se 
domnívat, že uchazeči o studium ovládají základní úlohy na elektrolýzu tavenin čistých látek, úlohy zaměřené na elektrolýzy tavenin směsí, ve kterých je nutné využít zadané elektrodové potenciály jednotlivých kovů, jim činí obtíže. Na základě analýzy učebnic středoškolské chemie bylo zjištěno, že tato problematika je podrobněji zmíněna pouze v Chemii pro čtyřletá gymnázia (Mareček et al., 2005b). V RVP G učivo elektrolýza není explicitně zmíněno, nicméně téma lze zařadit $\mathrm{k}$ učivu výpočty $\mathrm{v}$ chemii.

\subsection{Analýza úloh s nedostatečnou citlivostí}

Analýza úloh z obecné chemie odhalila tři témata, která obsahovala necitlivé úlohy. Mezi tato témata patřily (i) tepelný rozklad látky; (ii) rychlostní rovnice a (iii) chemické rovnováhy.

První vymezené téma tepelný rozklad látek bylo kromě jedné necitlivé úlohy zařazeno $\mathrm{v}$ dalších jedenácti úlohách, které byly zadány $\mathrm{v}$ rámci přijímacího řízení. Necitlivá úloha se zaměřovala na tepelný rozklad dusičnanu olovnatého, správné vyčíslení redoxní reakce a následný výpočet látkového množství jednoho z produktů. Přestože úloha vykázala poměrně vysokou úspěšnost $69 \%$, nelze ji považovat za vhodnou vzhledem $\mathrm{k}$ vypočteným koeficientům citlivosti $(\mathrm{ULI}(1 / 2)=0,08 ; \mathrm{RIR}=0,13)$. Úloha kombinovala výpočet molární hmotnosti produktu spolu s vyčíslením slovně-zadané redoxní rovnice. Na rozdíl od ostatních úloh, které se týkaly stejného tématu (tepelný rozklad látek), byla pro úspěšné vyřešení této úlohy potřeba vysokého počet kroků, což mohlo být prŕččinou nižší citlivosti. Jedním z možných důvodů neúspěšného řešení mohlo být chybné vyčíslení chemické rovnice, což vedlo $\mathrm{k}$ nevhodností jednoho z nabízených distraktorů (tj. tuto chybnou odpověd' volili častěji úspěšnější řešitelé než řešitelé méně úspěšní) a úloha tak nedostatečně rozlišovala mezi řešiteli úspěšnými a neúspěšnými. Obdobně nízký koeficient citlivosti vykazovala i velmi obdobná položka, která byla zaměřena na tepelný rozklad oxidu rtutnatého. Úloha vykazovala velmi vysokou úspěšnost $91 \%$ avšak s tím spojenou nízkou citlivost (ULI $(1 / 2)=0,10$ a RIR $=0,23)$. Nízká hodnota koeficientu ULI(1/2) je způsobena velmi vysokou úspěšností, což je limitujícím faktorem pro tento koeficient citlivosti a při zohlednění koeficientu RIR lze tuto položku považovat za přijatelně citlivou. Je pravděpodobné, že vysoká úspěšnost v úloze byla způsobena nízkým počtem krokům $\mathrm{k}$ jejímu úspěšnému vyřešení. Na úlohu lze tedy pohlížet jako na úlohu motivační bez dostatečné funkce rozlišit úspěšné uchazeče od uchazečů neúspěšných. Ostatní úlohy týkající se tématu tepelný rozklad látek byly zaměřeny bud’ na výpočet molární hmotnosti rozkládané látky či na výpočet poměru objemů/hmotností dvou látek vystupujících $\mathrm{v}$ dané reakci a vykazovaly vhodnou úspěšnost $(50 \%$ až $73 \%$ ) i citlivost. V předchozí studii Štefanová (2005) poukazovala právě na úlohy zaměřené na tepelný rozklad látek jako na úlohy s vysokou citlivostí. Výše uvedená zjištěni lze shrnout následovně: úlohy zaměřené na výpočty spojené s tepelný rozkladem látky jsou vhodné, pokud nezahrnují další obtížný krok, např. vyčíslení slovně zadané redoxní reakce. Vzhledem k RVP G lze výše analyzovaný tematický celek zařadit $\mathrm{k}$ učivu výpočty $\mathrm{v}$ chemii.

Druhé vymezené téma, které se zaměřovalo na rychlostní rovnici, bylo obsaženo ve dvou úlohách. Obě tyto úlohy vykázaly úspěšnost přibližně $35 \%$, avšak též poměrně nízkou citlivost - hodnoty ULI $(1 / 2)$ a RIR se pohybovaly na intervalu 0,12 až 0,20 . Předpokladem nízké citlivosti mohlo být, že žáci správnou odpověd pouze tipovali či se na správnou odpověd' snažili přijít doplněním zadaných hodnot do výsledných vztahů (úloha byla zaměřena na určení závislosti rychlosti na koncentraci výchozích látek tzv. metodou počátečních rychlostí). Úloha tedy netestovala znalosti z oboru chemie a nerozlišovala úspěšné uchazeče od uchazečů neúspěšných. Přestože v RVP G téma přímo souvisí s učivem rychlost chemických reakcí, na základě analýzy středoškolských učebnic chemie se zjistilo, že problematika byla stručně vysvětlena pouze v učebnici autorů Vacík et al. (1999).

Posledním tématem, ve kterém byly nalezeny necitlivé úlohy, byly chemické rovnováhy. Toto téma bylo obsaženo celkem v deseti úlohách, které byly zaměřeny na ovlivňování rovnovážné konstanty přidáním či odebráním reaktantu, resp. produktu, ustanovení rovnováhy v závislosti na $\mathrm{pH}$ a na výpočet rovnovážné konstanty. Dvě úlohy z deseti byly označené jako necitlivé, Jedna byla zaměřena na dvojici chemických rovnováh (a posunu těchto rovnováh $\mathrm{v}$ závislosti na změně $\mathrm{pH}$; rovnováhy byly $\mathrm{v}$ zadání zapsány), druhá byla zaměřena na ovlivnění chemické rovnováhy mezi chromanem a dichromanem $\mathrm{v}$ závislosti na změně pH (celá reakce byla opět v zadání zapsána). Koeficienty citlivosti těchto dvou položek se pohybovaly na intervalu 0,07 až 0,21 , což poukazuje na velmi malou rozlišovací schopnost úlohy. Je možné předpokládat, že možnou př́ičinou snížené citlivosti bylo, stejně jako v již zmíněné úloze o tepelném rozkladu dusičnanu olovnatého, vysoký počet kroků nutný $\mathrm{k}$ úspěšnému vyřešení úlohy. Tuto skutečnost podporuje i fakt, že citlivost zbylých osmi úloh byla vyhovující, v některých př́ípadech dokonce velmi dobrá, nebot koeficienty citlivosti nabývaly hodnot 0,21 až 0,47 . Vzhledem k tomu, že Martincová (2001) i Štefanová (2005) ve svém výzkumu poznamenaly, že úlohy zaměřené na problematiku chemických rovnováh obvykle vykazují zvýšenou náročnost, předpokládalo se, že tyto úlohy budou celkově vykazovat nižší úspěšnost. Nicméně úspěšnost obou necitlivých úloh činila $43 \%$, resp. $47 \%$. Uspěšnost všech (citlivých i necitlivých) námi analyzovaných úloh zaměřených na chemické rovnováhy kolísala a pohybovala se mezi 38 \% a $64 \%$. Výše 
uvedené skutečnosti lze shrnout tak, že úlohy zaměřené na chemické rovnováhy jsou vhodné za předpokladu, že $\mathrm{k}$ vyř̌šení úlohy není potřeba uvědomění si dalších souvislostí, např. vztahu mezi koncentrací oxoniových kationtů a pH. Téma chemická rovnováha je učivem uvedeným v RVP G.

\section{3 Úlohy dostatečně citlivé s adekvátní obtížností}

Vzhledem $\mathrm{k}$ tomu, že předchozí podkapitoly se zaměřily především na analýzu velmi obtížných či necitlivých úloh, $v$ této podkapitole jsou představeny úlohy, které naopak vykazovaly adekvátní úspěšnost (30 až $80 \%$ ) a zároveň přijatelnou citlivost, tedy položky vhodné pro účely přijímacího rrízení. Celkem bylo vytýčeno devět témat, které právě takovéto úlohy obsahovaly, z nichž pět bylo představeno v kapitolách 5.1 a 5.2: (i) výpočet $\mathrm{pH}$ kyseliny/zásady o dané koncentraci (nikoliv však směsi látek); (ii) elektronová konfigurace; (iii) elektrolýza chemicky čisté látky; (iv) tepelný rozklad látek; (v) chemické rovnováhy; (vi) teorie kyselin a zásad; (vii) výběr pravdivého tvrzení o kationtech; (viii) termochemie a (ix) redoxní reakce.

V následujícím textu jsou uvedena zbývající čtyři, dosud nepředstavená, témata z obecné chemie.

Ulohy zaměřující se na teorii kyselin a zásad byly v rámci přijímacího řízení zadány celkově čtyři. Ve všech případech byla dána dvojice částic a úkolem uchazeče bylo vybrat z nabízených možností tu, která obsahuje částice, které by ze zadané dvojice částic vznikly v př́padě, že by tyto částice chovaly jako kyseliny. Všechny úlohy vykazovaly velice vysokou citlivost. Koeficienty citlivosti nabývaly hodnot od 0,32 do 0,54 . Což poukazuje na to, že všechny položky dostatečně rozlišují úspěšné uchazeče od uchazeču neúspěšných a jsou velmi vhodnými pro účely přijímacího řízení. Úspěšnost jednotlivých úloh však byla různorodá a pohybovala se mezi $39 \%$ a $67 \%$. Př́ćčina tohoto rozptylu mohla souviset s počtem nutných kroků vedoucích k vyř̌šení jednotlivých úloh. Uvedené zjištění je v rozporu se závěry Štefanové (2005), která toto téma obecně označila za obtížné, avšak v souladu s Martincovou (2001). Vzhledem k tomu, že v RVP G není téma kyselin a zásad explicitně zmíněno, lze jej zařadit $\mathrm{k}$ učivu vlastnosti látek.

Analyzované testy dále obsahovaly dvě úlohy zaměrující se na výběr pravdivého tvrzení o kationtech (oxoniovém, resp. amonném). Tyto úlohy se zaměřovaly na strukturu iontu, typ vazby mezi jednotlivými částicemi tvořící ion a vlastnosti daného iontu. Obě úlohy vykazovaly poměrně vysokou úspěšnost - $64 \%$, resp. $66 \%$ a velmi vysokou citlivost - koeficienty citlivosti nabývaly hodnot mezi 0,30 a 0,41 . Vzhledem $\mathrm{k}$ vypočteným charakteristikám úloh lze tyto úlohy označit jako vhodné pro účely přijímacího řízení. Ve vztahu k RVP G lze téma zařadit k učivu stavba atomu či chemická vazba.

Tématermochemie bylo obsaženo ve čtyřech úlohách s různou úspěšností, která se pohybovala mezi $45 \%$ a $69 \%$ s tím, že všechny úlohy vykazovaly adekvátní až vysoké koeficienty citlivosti $(0,25$ až 0,42$)$. Rovněž se jedná o položky vhodné do přijímacího řízení. Zjištění je v rozporu se závěry Martincové (2001) a též se závěry autorů Tilahun a Tirfu (2016), kteří téma termochemie obecně shledávají jako téma velmi obtížné. Co se týče RVP G téma termochemie je obsaženo v učivu tepelné přeměny při chemických reakcí.

Analyzované testy obsahovaly celkem deset úloh zaměřující se na redoxni reakce. Tyto úlohy mohou být dále děleny na úlohy zaměřené na vyčíslení redoxní rovnice a na úlohy zaměřené na výběr redoxní rovnice. Úspěšnost úloh zaměřených na vyčíslování redoxní reakce se pohybovala mezi $54 \%$ a $87 \%$, koeficienty citlivosti nabývají hodnot na intervalu 0,18 až 0,41 . Rovněž úlohy zaměřené na výběr redoxní rovnice z nabídky nabývají obdobných hodnot - úspěšnost mezi $71 \%$ a $86 \%$ a koeficienty citlivosti na intervalu 0,20 až 0,33 . Úlohy spadající do tohoto tématu tedy vykazovaly obdobné vlastnosti, a to poměrně vysokou úspěšnost i citlivost nezávisle na způsobu zadání a zvoleném úkolu. Uvedené závěry jsou ve shodě s výzkumem Martincové (2001), která elementární redoxní reakce (s nízkým počtem myšlenkových kroků k úspěšnému vyř̌š̌ení úlohy) rovněž uvádí jako příklad úloh s nadprůměrnou úspěšností. Belháčová (2002) uvádí vyčíslování chemických reakcí jako oblast s velmi vysokou úspěšností, avšak z její práce není patrné, zda v rámci přijímacího ř́zení byly zadány redoxní reakce či reakce, během nichž nedocházelo ke změně oxidačních čísel prvků. V RVP G učivo redoxní reakce není přímo zmíněno, nicméně je možné jej zařadit $\mathrm{k}$ učivu stavba atomu, chemická vazba či vlastnosti látek.

\section{Limity výzkumu}

Cílem studie byla analýza oborových testů z chemie zadávaných v rámci přijímacího řízení na PřF UK. Uvedené závěry tedy nelze zobecnit na všechny absolventy českých či dokonce zahraničních středních škol a taktéž na realizaci přijímacích řízení na jiných českých či zahraničních vysokých školách.

Dále je důležité upozornit na skutečnost, že necitlivost je vlastnost úlohy (vycházející z jejího zadání) nikoliv tématu, kterého se úloha týká. Zařazení necitlivé úlohy do tematického celku si kladlo za cíl odhalit důvody necitlivosti dané úlohy. 
Podrobnějš́ komparací zjištěného závěru se závěry v teoretické části uvedených studií nebylo možné provést vzhledem $\mathrm{k}$ malému průniku analyzovaných témat $\mathrm{z}$ obecné chemie. $\mathrm{V}$ teoretické části uvedené studie se vždy zaobíraly pouze částí námi analyzovaných tematických celků.

Prezentovaná studie je dílčí studií, která byla zaměřena pouze na položkovou analýzu přijímacího testu jako jednoho možného prediktoru akademické úspěšnosti, a to vzhledem k rozsahu článku pouze na položkovou analýzu úloh spadající do oblasti obecné chemie. Na studii navazují další analýzy autorů článku - analýza úloh spadající do zbylých oblastí chemie (anorganické, organické a biochemie), které slouží jako podklad nejen pro úpravu přijímacího řízení na PřF UK, ale i úpravu obsahu povinných předmětů v prvním ročníku studijního programu Chemie.

\section{Závěr}

V rámci analýzy oborového testu z chemie použitých v letech 2016 až 2019 v rámci přijímacího ř́zení na PřF UK bylo odhaleno celkem pět tematických celků z oblasti obecné chemie, které obsahovaly úlohy obtížné pro uchazeče o studium chemie na PřF UK (stavová rovnice ideálního plynu (včetně výpočtu na základě zápisu chemické rovnice), výpočet $\mathrm{pH}$, elektronová konfigurace, iontový součin vody a elektrolýza). Na obtížnost některých úloh již upozorňovaly dřive realizované studie. S ohledem na přetrvávající nízkou úspěšnost $\mathrm{v}$ těchto oblastech doporučujeme těmto úsekům věnovat při př́ípravě budoucích studentů chemicky zaměřených studijních programů zvýšenou pozornost v rámci studia na vysoké škole.

Položková analýza následně odhalila tři témata, která obsahovala necitlivé úlohy (tepelný rozklad látky, rychlostní rovnice a chemické rovnováhy). Necitlivost úlohy často souvisela s vysokým počtem kroků nutných $\mathrm{k}$ jejímu úspěšnému vyřešení. Na všechny v článku analyzované necitlivé úlohy vzhledem k tomu, že nejsou schopné odlišit úspěšné uchazeče od uchazečů neúspěšných, je možné nahližžet jako na úlohy nevhodné pro přijímací ř́izení, vyjma úloh s motivační funkcí (tedy necitlivých úloh s vysokou úspěšností).

Podrobnou analýzou úloh bylo vytýčeno pět témat, které lze považovat za nevhodná pro účely přijímacího řízení (aplikace stavové rovnice ideálního plynu, výpočet $\mathrm{pH}$ směsi (kyselina + zásada), iontový součin vody, elektrolýza směsi látek s využitím elektrodových potenciálů a závislost rychlosti reakce na počátečních koncentracích výchozích látek). Nevhodnost témat plyne ze skutečnosti, že tato témata jsou v běžných středoškolských učebnicích zmíněna pouze okrajově a úlohy, jejichž předmětem byla výše uvedená témata, byly bud' velmi obtížné či (a zároveň) necitlivé.

V neposlední řadě položková analýza odhalila devět témat z oblasti obecné chemie, které obsahovaly pouze úlohy s adekvátní náročností a taktéž citlivostí (výpočet $\mathrm{pH}$ kyseliny/zásady o dané koncentraci (nikoliv však směsi látek), elektronová konfigurace, elektrolýza chemicky čisté látky, tepelný rozklad látek, chemické rovnováhy, teorie kyselin a zásad, struktura iontů, termochemie a redoxní reakce), přestože tři z témat (chemické rovnováhy, teorie kyselin a zásad a $\mathrm{pH}$ ) byla považována $\mathrm{v}$ předchozích výzkumech za náročné partie středoškolské chemie. V̌̌echna uvedená položky věnované uvedeným tématům lze považovat s ohledem na parametry jednotlivých položek za vhodná pro účely přijímacího rrízení.

Výše uvedené závěry mohou být reflektovány nejen v úpravě přijímacího řízení na vysoké školy, ale i v obsahu př́pravných kurzů $\mathrm{k}$ přijímacím zkouškám, případně i obsahu předmětu Obecná chemie na vysoké škole.

\section{Poděkování}

Tvorba př́spěvku byla podpořena grantovým programem Univerzitní výzkumná centra UK č. UNCE/ HUM/024 a projektem Progres Q17.

\section{Literatura}

Benešová, M., et al. (2002). Odmaturuj z chemie (1. vydání). Didaktis, spol. s r.o.

Belháčová, Z. (2009). Přijímací zkoušky na vysoké školy a nová maturita z chemie [Diplomová práce, Univerzita Karlova]. Repozitář Univerzity Karlovy. https://dspace.cuni.cz/handle/20.500.11956/22792

Berger, S. J. (2012). The rise and demise of the SAT: The University of California. American Educational History, 39(1), 165-180.

Brown, H. D. (2003). Language assessment: principles and classroom practices (1st ed.). Pearson/Longman.

Cowan, N. (2001). The magical number 4 in short-term memory: A reconsideration of mental storage capacity. Behavioral and Brain Sciences, 24(1), 87-185. https://doi.org/10.1017/S0140525X01003922 
Čipera, J., Klímová, H., \& Čiperová, M. (1985). Ovlivňování složitosti úloh. Pedagogika, (26), 563-574.

Herridge, M. (2016). Student Identification of Problem Topics in General Chemistry. [Diplomová práce, Missouri State University]. Archiv Missouri State University. https://bearworks.missouristate.edu/theses/2964/

Huvarová, M. (2010). Nejpouživanějši středoškolské učebnice chemie na gymnáziích. [Bakalářská práce, Univerzita Palackého v Olomouci]. Archiv Univerzity Palackého. https://theses.cz/id/bmn3n5/

Chráska, M. (1999). Didaktické testy. Paido.

Chvál, et al. (2015). Hodnocení výsledkư vzděláváni didaktickými testy. TISKÁRNA BíLÝ SLON, s. r. o.

Jedličková, A. (2007). Přijímací zkoušky z chemie - analýza a tvorba úloh. [Diplomová práce, Univerzita Karlova]. Repozitář Univerzity Karlovy. https://dspace.cuni.cz/handle/20.500.11956/93513

Martincová, J. (2001). Souhrnná analýza úloh přijímacích testi̊ z chemie na Př́rodověděckou fakultu UK z let 1995, 1996, 1998 a 2000. [Disertační práce, Univerzita Karlova]. Přírodovědecká Fakulta UK.

Mareček, A., \& Honza, J. (2005a). Chemie pro čtyřletá gymnázia 1. díl (3. vydání). Nakladatelství Olomouc, s. r. o.

Mareček, A., \& Honza, J. (2005b). Chemie pro čtyřletá gymnázia 2. díl (3. vydání). Nakladatelství Olomouc, s.r.o.

Miller, G. A. (1956). The magical number seven, plus or minus two: Some limits on our capacity for processing information. Psychological Review, 63(2), 81-97. https://doi.org/10.1037/h0043158

MŠMT ČR. (2007). Rámcový vzdělávací program pro gymnázia: RVP G. Výzkumný ústav pedagogický v Praze.

Pikálková, S., Vojtěch, J., \& Kleňha, D. (2014). Úspěšnost absolventů středních škol ve vysokoškolském studiu, předčasné odchody ze vzdělávání. Národní ústav pro vzdělávání.

PřF UK (Př́rodovědecká fakulta Univerzity Karlovy). (2021). Fakulta / Uchazeči o studium / Podmínky přijímacího ř́izení k bakalářskému studiu na Př́rodovědecké fakultě pro akademický rok 2021/2022. https://www.natur.cuni.cz/fakulta/uchazeci/

podminky-prijimaciho-rizeni-k-bakalarskemu-studiu-na-prirodovedecke-fakulte-pro-akademicky-rok-2021-2022

Rubešová, J. (2009). Souvisí úspěšnost studia na vysoké škole se středoškolským prospěchem? Pedagogická orientace, 19(3), 89-103.

Rusek, M., Vojír, K., \& Chroustová, K. (2021). An investigation into freshman chemistry teacher students' difficulty in performing chemistry calculations. In M. Nodzynska (Ed.), Scientific Thinking in Chemical Education (pp. 61-68). Pedagogical University of Kraków.

Škaloudová, A. (2003). Predikce úspěšnosti ve studiu učitelství. [Disertační práce, Univerzita Karlova]. Pedagogická fakulta UK.

Šrámek, M., \& Teplá, M. (2020). Prediktory akademického úspěchu. In A. Vargová \& K. Szarka. 15. Medzinárodná konferencija študentov doktorandského štúdia v oblasti teórie prírodovedného vzdelavania (Zborník príspevkov). 1. vyd. Komárno: J. Selye University, Komárno, Slovak Republic, (s. 96-100).

Šrámek, M., \& Teplá, M. (2021). „Problematické“ partie středoškolské chemie vyplývající z analýzy přijímacího řízení na Př́rodovědeckou fakultu Univerzity Karlovy. In V. Machková, 16th International seminar for PhD students of chemistry didacticsand related doctoral study programs. PROCEEDINGS. 1. vyd. Univerzita Hradec Králové (s. 101-108).

Štefanová, L. (2005). Přijímací zkoušky z chemie - analýza a tvoba úloh. [Diplomová práce, Univerzita Karlova]. Repozitář Univerzity Karlovy. https://dspace.cuni.cz/handle/20.500.11956/98334

Taherdoost, H. (2016). Validity and reliability of the research instrument; How to test the validation of a questionnaire/survey in a research (August 10, 2016). Available at SSRN: https://ssrn.com/abstract $=3205040$ or https://doi.org/10.2139/ssrn.3205040

Tilahun, K., \& Tirfu, M. (2016). Common Difficulties Experiences by 12 Grade Students in Learning Chemistry in Ebinat Preparatory School. Semantic Scholar, 6(2), 16-32.

Vacík, J., et al. (1999). Přehled středoškolské chemie (4. vydání). Státní pedagogické nakladatelství, a.s.

Varma, S. (2020). Preliminary item statistics using point-biserial correlation and P-Values. Eddata. https://eddata.com/wp-content/uploads/2015/11/EDS_Point_Biserial.pdf 